\begin{tabular}{|l|l|l||}
\hline \multicolumn{2}{|c|}{ PublisherInfo } \\
\hline \hline PublisherName & $:$ & BioMed Central \\
\hline \hline PublisherLocation & $:$ & London \\
\hline \hline PublisherImprintName & $:$ & BioMed Central \\
\hline \hline
\end{tabular}

\title{
Acoustics of breathing
}

\begin{tabular}{|l|l|l||}
\hline \multicolumn{2}{|c|}{ ArticleInfo } \\
\hline \hline ArticleID & $:$ & 4291 \\
\hline \hline ArticleDOI & $:$ & $10.1186 /$ ccf-2000-webreport1743 \\
\hline \hline ArticleCitationID & $:$ & webreport1743 \\
\hline \hline ArticleSequenceNumber & $:$ & 32 \\
\hline \hline ArticleCategory & $:$ & Web report \\
\hline ArticleFirstPage & $:$ & 1 \\
\hline \hline ArticleLastPage & $:$ & 2 \\
\hline \hline & & RegistrationDate : 2000-3-10 \\
\hline ArticleHistory & $:$ & OnlineDate \\
\hline \hline ArticleCopyright & $:$ & Current Science Ltd2000-3-10 \\
\hline \hline ArticleGrants & $:$ & \\
\hline \hline ArticleContext & $:$ & 1305444 \\
\hline \hline
\end{tabular}




\section{Overview}

The Respiratory Acoustics Laboratory Environment (R.A.L.E.) Repository was set up by Dr Hans Pasterkamp from the University of Manitoba and presents digital recordings of respiratory sounds in health and disease states. Twelve respiratory sounds are available ranging from normal breathing sounds to those of wheezing and grunting. Accompanying each sound recording is a brief description of the patient from whom the recording was taken and a respirosonogram which provides a visual representation of the respiratory sound recording. In addition, visitors are invited to download demonstrations of educational programmes on heart and lung sounds.

\section{Content}

The site has a clear lay out, is simple to navigate and is a useful tool for medical students, nurses and physicians and indeed anyone who wants to learn more about respiratory sounds. The site has received the Oncology Nursing Society Editor's Choice Award and has been commended by the Medical Resource Reviews Database.NB: R.A.L.E is a registered tradename.

\section{Other comments}

03.10 .00

\section{References}

1. The R.A.L.E. Repository. [http://www.rale.ca] 